\title{
Hubungan Intensitas Menggunakan Facebook dengan Kecenderungan Nomophobia pada Remaja
}

\author{
Ria Wahyuni, Harmaini \\ Fakultas Psikologi Universitas Islam Negeri Sultan Syarif Kasim Riau \\ email:harmaini@uin-suska.ac.id
}

\begin{abstract}
Abstrak
Pada masa sekarang ini, perkembangan sosial media terutama facebook sangat pesat. Hal ini memicu remaja untuk menggunakan facebook semakin meningkat yang akan menyebabkan kecenderungan menjadi nomophobia. Penelitian ini bertujuan untuk mengkaji secara ilmiah mengenai ada tidaknya hubungan antara intensitas penggunaan facebook terhadap kecenderungan menjadi nomophobia pada remaja. Subjek dalam penelitian ini adalah siswa SMA Negeri 02 Bengkalis dengan teknik pengambilan sampel yang digunakan adalah adalah purposive sampling sebanyak 171 siswa. Data penelitian diperoleh dengan menggunakan skala yang diperoleh melalui aspekaspek intensitas penggunaan facebook yang dikemukakan oleh Ellison dkk (2007), dan karakteristik nomophobia yang diuraikan oleh Bragazzi \& Del Puente (2014). Hasil analisis data menunjukan korelasi intensitas penggunaan facebook dengannomophobia dengan korelasi sebesar $R=0,272$ dengan taraf signifikansi $0,000(p<0,05)$, maka dapat ditarik kesimpulan bahwa ada hubungan antara intensitas penggunaan facebook dengan kecenderungan menjadi nomophobia pada remaja. Hal ini berarti tinggi rendahnya intensitas penggunaan facebook berhubungan dengan kecenderungan menjadi nomophobia. Selanjutnya nilai sumbangsih variabel intensitas penggunaan facebook terhadap variabel kecenderungan menjadi nomophobia adalah $7,4 \%$, sisanya $92,6 \%$ di pengaruhi oleh variabel lain.
\end{abstract}

Kata kunci: intensitas penggunaan facebook, menjadi nomophobia, remaja.

\section{Correlation Of Facebook Use Intensity With Tendency Becoming Nomophobia on Adolescent}

\begin{abstract}
Nowadays, social media development especially facebook is very fast. It sparks adolescent to use facebook and it increases as tendency named nomophobia. This research aims to scientifical review whether there is correlation between facebook use intensity on tendency that becomes nomophobia or not. This research subject is students of SMA Negeri 02 Bengkalis by using purposive sampling technique with 171 students. Research data is gotten by using scale from intensity aspects facebook user stated by Ellison dkk (2007) and nomophobia characteristics said by Bragazzi \& Del Puente (2014).. The data analysis result shows correlation of facebook use intensity with tendency becoming nomophobia with correlation $R=0.272$ with significant degree $0.000(p<0,05)$, therefore it can be concluded that there is correlation between facebook use intensity and tendency becomes nomophobia for adolescent. It means that facebook use intensity relates tendency to be nomophobia. After that, facebook use intensity variable contribution value towards tendency variable becomes nomophobia is $7.4 \%$ and $92.6 \%$ is influenced by other variables.
\end{abstract}

Keywords: facebook use intensity, nomophobia, adolescent

\section{Pendahuluan}

Semakin hari teknologi komunikasi berkembang semakin pesat. Teknologi komunikasi adalah teknologi yang berhubungan jarak jauh. Teknologi komunikasi inilah yang memungkinkan seseorang dapat mengirim- kan informasi atau menerima informasi dari pihak lain yang letaknya berjauhan. Perkembangan komunikasi teknologi ini dipicu dengan perkembangan internet. Dengan adanya internet komunikasi jarak jauh dan menciptakan penyajian informasi menjadi mudah. Hampir setiap orang sekarang terhubung dengan in- 
ternet, baik itu melalui komputer atau laptop, smartphone, maupun tablet. Perkembangan situs jejaring sosial di dunia maya pada masa sekarang ini berjalan dengan sangat cepat. Salah satu jenis situs jejaring sosial yang saat ini sedang populer di Indonesia adalah facebook. Facebook telah menarik perhatian sebagian besar pengguna internet di Indonesia. Hal ini dibuktikan dengan jumlah penggunanya yang sangat besar.

Perkembangan facebook yang begitu pesat menjadikan Indonesia sebagai negara dengan pengunjung facebook terbanyak seAsia Pasifik dengan traffic rank yang terus meningkat dari waktu ke waktu (Top Sites Alexa, 2010). Menurut data dari Webershandwick, perusahaan public relations dan pemberi layanan jasa komunikasi, untuk wilayah Indonesia ada sekitar 65 juta pengguna facebook aktif. Sebanyak 33 juta pengguna aktif per harinya, 55 juta pengguna aktif yang memakai perangkat mobile dalam pengaksesannya per bulan dan sekitar 28 juta pengguna aktif yang memakai perangkat mobile per harinya. Menurut lembaga riset Forester Reasearch, kebanyakan pengguna facebook adalah mereka yang tergolong usia remaja (Kemenkominfo, 2014). Facebook memang situs jejaring sosial yang sudah menjadi bagian yang tidak bisa terpisahkan dalam kehidupan sehari-hari bagi kebanyakan remaja. Tidak heran apabila pengguna facebookbisa 5-6 kali memperbaharui statusnya, bahkan ada yang lebih dari itu, sedangkan lamanya waktu yang dihabiskan untuk mengakses facebook dalam sehari ialah lebih dari 1,3 jam (kategori Heavy users menurut The Graphic, Visualization dan Utility Center di The Georgia Institute of Technology). Tingginya tingkat penggunaan facebook menyebabkan individu tidak bisa berjauhan dengan handphone. Seseorang melakukan suatu kegiatan dikarenakan ada dorongan dalam dirinya, dan kegiatan yang dilakukan secara terus menerus sering disebut intensif. Intensitas juga berhubungan dengan frekuensi, yaitu seberapa sering kegiatan tersebut dilakukan (Simatupang, 2011).

Menurut Chaplin (2006) di katakan intensitas adalah kekuatan yang mendukung suatu pendapat atau suatu sikap. Menurut Ka- loh (dalam Ruhban, 2013) intensitas merupakan tingkat keseringan seseorang dalam melakukan suatu kegiatan tertentu yang didasari rasa senang dengan kegiatan yang dilakukan tersebut. Jadi perasaan senang dalam melakukan suatu kegiatan sangat mempengaruhi seseorang dalam melaksanakan suatu kegiatan dalam hal ini yaitu mengoprasikan facebook.

Dari uraian diatas dapat disimpulkan bahwa intensitas merupakan tingkat keseringan seseorang melakukan suatu kegiatan tertentu dikarenakan suatu dorongan dari dalam dirinya dan kegiatan tersebut dilakukan secara terus menerus. Adapun aspek-aepek intensitas penggunaan facebook menurut Ellison, dkk (2007) yaitu: banyaknya teman (friends) yang dimiliki pengguna, lamanya pengguna menghabiskan waktu mengakses facebook, hubungan emosional antara pengguna dengan facebook, facebook menjadi bagian sehari-hari pengguna, dan untuk bertemu teman-teman baru (meet new people) dalam facebook. Menurut Securenvoy (2012) rasa takut yang berlebihan saat kehilangan handphone disebut dengan nomophobia. Nomophobia adalah jenis fobia yang ditandai dengan kecemasan dan ketakutan yang berlebihan jika seseorang kehilangan atau jauh dari ponselnya. Orang-orang, terutama remaja yang menderita nomophobia selalu hidup dalam kekhawatiran dan selalu was-was atau cemas dalam meletakkan poselnya, kehabisan baterai atau pulsa, atau karena tidak memiliki jaringan. Beberapa uraian diatas menggambarkan bahwa facebook yang menjadi alat seseorang untuk berkomunikasi melalui media internet menyebabkan seseorang tergantung dengan facebook. Ketergantungan tersebut dapat terjadi dalam berbagai bentuk. Salah satu bentuk tersebut adalah seseorang tidak mau hidup dalam kekhawatiran dan selalu was-was atau cemas dalam meletakkan poselnya, kehabisan baterai atau pulsa, atau karena tidak memiliki jaringan.

Dari permasalahan di atas maka hipotesis dalam penelitian ini adalah ada hubungan antara intensitas penggunaan facebook terhadap kecenderungan menjadi nomophobia. 
loh (dalam Ruhban, 2013) intensitas merupakan tingkat keseringan seseorang dalam melakukan suatu kegiatan tertentu yang didasari rasa senang dengan kegiatan yang dilakukan tersebut. Jadi perasaan senang dalam melakukan suatu kegiatan sangat mempengaruhi seseorang dalam melaksanakan suatu kegiatan dalam hal ini yaitu mengoprasikan facebook.

Dari uraian diatas dapat disimpulkan bahwa intensitas merupakan tingkat keseringan seseorang melakukan suatu kegiatan tertentu dikarenakan suatu dorongan dari dalam dirinya dan kegiatan tersebut dilakukan secara terus menerus. Adapun aspek-aepek intensitas penggunaan facebook menurut Ellison, dkk (2007) yaitu: banyaknya teman (friends) yang dimiliki pengguna, lamanya pengguna menghabiskan waktu mengakses facebook, hubungan emosional antara pengguna dengan facebook, facebook menjadi bagian sehari-hari pengguna, dan untuk bertemu teman-teman baru (meet new people) dalam facebook. Menurut Securenvoy (2012) rasa takut yang berlebihan saat kehilangan handphone disebut dengan nomophobia. Nomophobia adalah jenis fobia yang ditandai dengan kecemasan dan ketakutan yang berlebihan jika seseorang kehilangan atau jauh dari ponselnya. Orang-orang, terutama remaja yang menderita nomophobia selalu hidup dalam kekhawatiran dan selalu was-was atau cemas dalam meletakkan poselnya, kehabisan baterai atau pulsa, atau karena tidak memiliki jaringan. Beberapa uraian diatas menggambarkan bahwa facebook yang menjadi alat seseorang untuk berkomunikasi melalui media internet menyebabkan seseorang tergantung dengan facebook. Ketergantungan tersebut dapat terjadi dalam berbagai bentuk. Salah satu bentuk tersebut adalah seseorang tidak mau hidup dalam kekhawatiran dan selalu was-was atau cemas dalam meletakkan poselnya, kehabisan baterai atau pulsa, atau karena tidak memiliki jaringan.

Dari permasalahan di atas maka hipotesis dalam penelitian ini adalah ada hubungan antara intensitas penggunaan facebook terhadap kecenderungan menjadi nomophobia.

\section{Metode}

\section{Jenis Penelitian}

Jenis penelitian adalah penelitian kuantitatif deskriptif. Sedangkan jenis penelitian deskriptif yang digunakan adalah penelitian korelasional. Penelitian korelational adalah metode yang dirancang untuk menentukan tingkat hubungan variabel-variabel yang berbeda dalam suatu populasi.

\section{Subjek}

Populasi adalah keseluruhan elemen/ anggota dari suatu wilayah yang menjadi sasaran penelitian atau merupakan keseluruhan dari objek penelitian. Pada penelitian ini, Populasi yang dimaksud peneliti adalah seluruh siswa dan siswi SMA Negeri 02 Bengkalis. Jumlah populasi siswa yang duduk di kelas $\mathrm{X}$, XI dan XII adalah 683 orang.

Sampel adalah kelompok anggota yang menjadi bagian dari populasi sehingga juga memiliki karakteristik populasi. Arikunto (2006) berpendapat bahwa, apabila subjek10-25\% atau $25-50 \%$ atau lebih. Dari pendapat Arikunto diatas, dalam penelitian ini peneliti mengambil sampel sejumlah $25 \%$ dari 683 siswa di SMA Negeri 02 Bengkalis. Berdasarkan penghitungan sampel $25 \%$ dari 683 siswa didapatkan sejumlah 171 responden.

Teknik pengambilan sampel yang digunakan adalah purposive sampling. Teknik purposive sampling adalah teknik penentuan sampel berdasarkan individu yang sesuai dengan kriteria sampel yang telah ditentukan peneliti. Yang menjadi sampel dalam penelitian ini adalah siswa SMAN 02 Bengkalis. Adapun kerakteristik sampel yaitu:

a. Menggunakan facebook minimal 1 tahun, dikarenakan lamanya pengguna menggunakan facebook mempengaruhi jumlah pertemanan di media sosial facebook.

b. Menggunakan handphone atau smartphone yang memiliki aplikasi facebook.

\section{Pengukuran}

Alat ukur yang digunakan dalam mengumpulkan data berupa skala dan angket yang terdiri dari dua bagian, yaitu : alat ukur untuk intensitas penggunaan facebook 
dan alat ukur untuk kecenderungan menjadi nomophobia. Skala diberikan kepada masing-masing responden yang memenuhi kriteria subjek penelitian. Skala di berikan secara bersamaan dan terlebih dahulu di lakukan try out dengan subjek yang memiliki kriteria yang sama dengan subjek dalam penelitian.

\section{Analisis Data}

Dalam penelitian ini penulis menggunakan analisis statistik korelasi product moment dengan menggunakan bantuan program SPSS 17.00 for windows, karena teknik ini bertujuan untuk mengetahui ada atau tidaknya korelasi antara dua variabel (Arikunto, 2002).

\section{Hasil}

Menentukan sebarapa besar hubungan antarvariabel adalah dengan menggunakan koefesien korelasi atau indeks korelasi. Besarnya koefesien korelasi bergerak antara 0,000 sampai $+1,000$, yang disebut korelasi positif, atau antara 0,000 sampai $-1,000$, yang disebut korelasi negatif (Hartono,2010). Untuk menguji hipotesis yang diajukan apakah diterima atau ditolak, dilakukan analisis data. Teknik analisis data yang digunakan adalah korelasi product moment dari program SPSS 17,0 for windows.

Berdasarkan hasil analisis terhadap data penelitian, diperoleh koefesien korelasi ( $r$ ) sebesar 0,272 maka diperoleh nilai probabilitas $0.000 \quad(p<0.05)$. Dengan demikian, sesuai dengan ketentuan penerimaan dan penolakan hipotesis yang telah dikemukakan sebelumnya, maka hipotesis yang diajukan pada penelitian ini, yaitu "ada hubungan antara intensitas penggunaan facebook terhadap kecenderungan menjadi nomophobia pada remaja" diterima. Ini berarti bahwa tinggi rendahnya kecenderungan menjadi nomophobia pada remaja dipengaruhi oleh intensitas penggunaan facebook, besarnya hubungan dilihat dari uji korelasi sebesar 0,272.

Berdasarkan pedoman penafsiran koefesien korelasi oleh Sugiyono (1999), maka nilai koefesien korelasi penelitian yaitu sebesar 0,272 berada pada interpretasi koef- esien korelasi dengan tingkat rendah.

Berdasarkan hasil analisis data yang dilakukan menunjukan koefesien korelasi dari kedua variabel sebesar 0,272 dengan probabilitas sebesar 0,000 $(p<0,05)$. Nilai tersebut menunjukan bahwa ada hubungan positif yang signifikan antara intensitas penggunaan facebook dengan kecenderungan menjadi nomophobia pada remaja. Artinya semakin tinggi intensitas penggunaan facebook maka semakin tinggi pula kecenderungan menjadi nomophobia pada remaja, sebaliknya semakin rendah intensitas penggunaan facebook maka semakin rendah pula kecenderungan menjadi nomophobia pada remaja.

\section{Pembahasan}

Pembentukan tinggi rendahnya intensitas penggunaan facebook pada remaja bisa dilihat melalui perceived behavior control (PBC). PBC adalah ukuran sejauh mana individu percaya tentang mudah atau sulitnya menampilkan tingkah laku tertentu (Hogg \& Vaughan dalam Ruhban, 2013). Adapun menurut Felman (dalam Ruhban, 2013) PBC adalah persepsi tentang kesulitan atau kemudahan dalam melaksanakan tingkah laku, berdasarkan pada pengalaman sebenarnya dan hambatan yang diantisipasi dalam melaksanakan tingkah laku tertentu. Jika dilihat dari pengertian PBC, tinggi rendahnya intensitas penggunaan facebook dipengaruhi oleh keyakinan pengguna tentang manfaat yang didapat ketika menggunakan facebook. Keyakinan tentang manfaat ini dapat berupa bisa berkomunikasi dengan teman-teman, bersosialisasi, dan menambah relasi juga mencari informasi-informasi yang dibutuhkan. Keyakinan-keyakinan itulah yang turut berpartisipasi dalam membentuk intensitas penggunaan facebook yang tinggi. Begitu pula sebaliknya ketika keyakinan yang terbentuk kecil maka intensitas penggunaan facebook juga cenderung rendah.

Selanjutnya yang turut berkontribusi terhadap terbentuknya tingkah laku dalam pembentukan perilaku dalam menggunakan facebook adalah sikap dan norma subyektif. Sikap adalah keadaan mental dan saraf 
dari kesiapan yang diatur melalui pengalaman yang memberikan pengaruh dinamik atau terarah terhadap respon individu pada semua objek dan situasi yang berkaitan dengannya (Allport dalam Inayati, 2011). Adapun pengertian norma subyektif menurut Hogg dan Vaughan (dalam Ruhban, 2013) adalah produk dan persepsi individu tentang beliefs yang dimiliki orang lain. Ketika seseorang memiliki kepercayaan positif dan memandang bahwa facebook bisa memberikan manfaat bagi penggunanya, maka hal ini akan mempengaruhi perilaku seseorang dalam mengguanakan facebook, tetapi ketika individu memandang bahwa facebook memberikan dampak buruk maka individu tidak akan menggunakan facebook. Ditambah lagi banyaknya kasus-kasus yang terjadi akibat media sosial, misalnya penculikan atau pemerkosaan sedikit banyak berpengaruh terhadap individu untuk menggunakan facebook.

Selaras dengan PBC, sikap dan norma subyektif yang membentuk perilaku seseorang dalam menggunakan facebook, kecenderungan nomophobia. Menurut Kalaskar P.B (2015) juga disebabkan oleh kecanduan menggunakan aplikasi sosial media maupun aplikasi yang lainnya. Kecenderungan menjadi nomophobia itu sendiri adalah ketakutan atau kepanikan yang berlebihan saat berjauhan atau saat tidak menggunakan handphone.

\section{Kesimpulan}

Berdasarkan hasil penelitian yang telah dilakukan diperoleh kesimpulan bahwa ada hubungan antara intensitas penggunaan facebook terhadap kecenderungan menjadi nomophobia pada remaja. Remaja dalam penelitian ini memiliki intensitas penggunaan facebook yang rendah dan kecenderungan untuk menjadi nomophobia dalam ketegori sedang. Pembentukan tinggi rendahnya intensitas penggunaan facebook pada remaja dipengaruhi oleh keyakinan tentang manfaat yang didapat ketika mengakses facebook, selanjutnya di tentukan juga oleh sikap dan norma subyektif yang dimiliki oleh pengguna facebook.

\section{Daftar Pustaka}

Affandi, \& Dewi, F,P. (2011). Pengaruh Intensitas Pemakaian Facebook terhadap Perkembangan Sosial Remaja di SMP Taruna Dra. Zulaeha. Fakultas Psikologi, Universitas Islam Negeri Maulana Malik Ibrahim, Malang

Anwesha (2012) Nomophobia:7 signs you have it! Di unduh tanggal 13 februari 2015 m.boldsky.com/health/disorderscure/2012/signs-of-nomophobia031482.html.

Arikunto, S. (2002). Prosedur Penelitian Suatu Pendekatan Praktek.. Jakarta: PT Rineka Cipta

Azwar, S, (2012). Penyusunan skala psikologi. Yogyakarta: pustaka pelajar

Azwar, S, (2011). Metode Penelitian. Yogyakarta: Pustaka Pelajar

Azwar, S. (2009). Dasar-dasar Psikometri, Yogyakarta: pustaka pelajar

Bragazzi, N.L., \& Del Puente, G. (2014). A Proposal for Including Nomophobia in the New DSM-V. psychology Research and Behavior Management, 7, 155.

Chairunnisa. (2010), hubungan Intensitas Mengakses Facebook dengan Motivasi Belajar Siswa MAN 13 Jakarta. Skripsi UIN Syarif Hidayatullaha Jakarta. Diterbitkan

Chaplin, J. P. (2008). Kamus Lengkap Psikologi. Jakarta: PT Raja Grafindo Persada

Dixit, S., Shukla, H., Bhagwat, A., Bindal, A., Goyal, A., Zaidi, A. K., \& Shrivastava, A. (2010). A Study to Evaluate Mobile Phone Dependence Among Students of a Medical College and Associated Hospital of Central India. Indian journal of community medicine: official publication of Indian Association of Preventive \& Social Medicine, 35(2), 339-341.

Donny. B. U. (2010). Privasi Diri disitus Jejaring Sosial Facebook. penelitian internet sehat. www.internetsehat.org Eduqo.com (2012). Educo: Fenomena Nomo- 
phobia diunduh pada tanggal 09 september 2014 http://www.eduqo com/2012/12/fenomena-nomophobia. html

Ellison, N. B., Steinfield, C., \& Lampe, C. (2007). The Benefits Of Facebook "Friends:" Social Capital And College Students Use Of Online Social Network Sites. Journal of ComputerMediated Communication, 12 (4), 1143-1168

Forgays, D.K., Hyman, I., \& Schreiber, J,. (2014). Texting Everywhere for Everything: Gender and Age Differences in Cell Phone etiquette And Use. Vol. 31. 314-321.

Hadi, S.(2002). Statistik. Yogyakarta: Pustaka pelajar

Hariyanti, D. (2011). Remaja, 64 persen Pengguna Jejaring Sosial. Jurnal.com

Hurlock. Elizabeth. B. ( 20002 Psikologi Perkembangan Suatu Pendekatan Sepanjang Rentang Kehidupan. Edisi ke lima Jakarta: Erlangga

Horrigan, J.B. 2002. New Internet Users : What They do Online, What They don't and Implikacations for the ,net"s future. Pew internet and American life project.Hal 1-27

Hsu, M. H, Chang, C. M, Lin, H.C, \& Lin, Y.W. (2015). Determinants of Continued Use of Social Media: The Perspectives of Uses and Gratifications Theory and Perceived Interactivity. Information research. Vol.20. No.2.

Iskandar, A.R (2013). Perbedaan Intensitas Penggunaan Facebook Terhadap Sense Of Community Pada Komunitas Pecinta Bis (Bismania). Http://www.academia.edu/6681121/ perbedaan_intensitas_penggunaan diunduh pada tanggal 19 Maret 2015

Inayati, I. N. (2011). Pengaruh sikap, norma subyektif dan perceived behavior control terhadap kesiapan guru pai atas kebijakan dimasukannya mata pelajaran pendidikan agama islam dalam ujian nasional (sur- vei di sma negeri dan smk neg eri se-kota Malang). Skripsi. Malang Universitas Islam Negeri.

Jena, R.K. (2015). Compulsive use of smart phone and its effect on engaged learning and nomophobia. Smart journal of business management studiest. No. 1. Vol. 1-11.

Juditha, C., (2011), Hubungan Pengggunaan Situs Jejaring Sosial Facebook Terhadap Perilaku Remaja Di Kota Makassar, 13. 1.

Juhaidi, facebook, Diakses tanggal 11 Maret2015http://www.puslit2.petra.ac. id

Kalaskar, P.B. (2015). A Study of Awareness of Development of Nomophobia Condition in Smartphone User Management Studies in Pune City. Ongoing Research in Management and IT. 65,320-326.

Kemenkominfo. (2014). Kominfo: Pengguna Internet Di Indonesia Capai 82 Juta Orang. diunduh pada tanggal 01 oktober 2014. http://kominfo.go.id/ index.php/content/detail/3980/ Kemkominfo\%3A+Pengguna+ Internet+di+Indonesia+Capai+82 $+\mathrm{Jut}$ a / $0 / \mathrm{b}$ erit a $\mathrm{s}$ a t ker.

King, A. L. S., Valença, A. M., \& Nardi, A. E. (2010). Nomophobia: the mobile phone in panic disorder with agoraphobia: reducing phobias or worsening of dependence?.Cognitive and Behavioral Neurology, 23(1), 5254. Computers in Human Behavior, 29(1), 140-144.

King, A.L.S., Valenca, A. M., Silva, A.C., Sancassiani, F., Machado, S., \& Nardi,A. E. (2014). „Nomophobia”: Impact Of Cell Phone Use Interfering With Symtoms And Emotions Of Individuals With Panic Disorder Compared With A Control Group. Clinical practice and epidemiology in mental health: $\mathrm{CP} \& \mathrm{EMH}, 10$, 28-35. Chicago

Marbun, J, (2014). Siswi SMA dikeroyok garagara status Facebook. m.republika. co.id/berit a/nasional/ 
daerah/14/08/30nb4dx0-siswisma-dikeroyok-garagara-statusfacebook di unduh pada tanggal 29 Maret 2015

Mohtar, E.K., \& Tasa.H. (2014). Komunikasi teraupeutik dan tingkat kecemasan keluarga pasien pra oprasi laparatomi/laparaskopi di rumah sakit Labuang Bji Makassar. Journal of medical surgical nursing. 1 (1) 29-32

Muller, M \& Davis.G.W. (2012). Transsynaptic Control of Presynaptic

Influx Achieves Homestatic King, A. L. S., Valença, A. M., Silva,

A. C. O., Baczynski, T., Carvalho, M. R., \& Nardi, A. E. (2013). Nomophobia: Dependency on virtual environments or social phobia?. Potentiation of Neurotransmitter Release. No.22. Vol. 1102-1108.

Nekie, J. (2013). Peran Smartphone dalam menunjang kinerja karyawan Bank Prismadana (studi pada karyawan Bank Prismadana cabang airmadidi. Jurnal Acta Diurna. Vol. 1. No. 1.

Niranti, D. F. (2013). Pola Perilaku Pengguna Facebook. Universitas Sebelas Maret Surakarta.

Noor, J. (2012). Metodologi Penelitian. Jakarta: Kencana

Pardede, P. (2013). Nomophobia. Di unggah pada tanggal 18 Maret 2015http://slazhpardede.com/2013/07/10/ no mophobia

Papalia, D.E. \& Olds, S.W. (1994). Human Depelopment. New York : McGrawHill, Inc

Qomariyah, N.A. (2009). Perilaku penggunaan Internet pada Kalangan Remaja di Perkotaan. Diunggah pada tanggal 05 februari 2015. www. academia.edu/4637668/perilaku_ penggunaan_internet_pada_ kalangan_remaja_di_perkotaan

Rachdiyanti. (2011). Hubungan antara SelfControl dengan Intensitas Penggunaan Internet Remaja Akhir. Skripsi Universitas Islam Negeri Syarif Hidayatullah Jakarta. Diterbitkan
Rubhan, Apris. (2013). Kontrol diri dan intensitas penggunaan facebook. jurnal online psikologi. Vol. 01 No. 02. Universitas Muhammadiyah Malang.

Santrock, John W, 2007 edisi ke sebelas : Perkembangan Anak Jilid 2. Jakarta : Erlangga.

Sarwono, W. S (1994). Psikologi Remaja. Jakarta: PT. Raja Grafindo

Securenvoy (2012). the population suffer from nomophobia the fear of being without their phone. diunduh pada tanggal 9 september 2014.http://www.securenvoy.com/blog/2012/02/16/66-of-thepopulation-suffer-from-nomophobiathe-fear-of-being-without-their-phone/

Sholikah, N \& Saifudin, M. (2013). Hubungan Intensitas Penggunaan Facebook dengan Motivasi Belajar Mahasiswa S1 Keperawatan Semester II Stikes Muhammadiyah Lamongan. Surya. vol. 03. No XVI 31-38.

Simatupang. (2011). Hubungan Intensitas Penggunaan Situs Jejaring Sosial (Facebook) dengan Harga Diri (Self Esteem) pada Siswa-Siswi SMK Negeri 1 Marangin Jambi tahun 2011. Skripsi Universitas Andalas. Diterbitkan.

Sugiyono. (2009). Statistik untuk penelitian. Bandung: CV Alfabeta

Tanaka, W. \& Terry-Cobo, S. (2008). Cellphone Addiction. Forbes. http:// www.forbes.com/2008/06/15/cell phone-addict-iphone-tech-wireless08cx wt0616addict.html

Tempo.co (2014). Tempo: Pengguna Facebook Di Indonesia Naik 6\%, Diakses pada tanggal 5 Februari 2015 dari http://www.tempo.co/read/ news/2014/06/29/072588907/Peng guna-Facebook-di-Indonesia-Naik6-Persen di akses oktober 2014

Top Sites Alexa. (2010). Artikel. http://www. alexa.com Diakses tanggal 21 Desember 2015.

Wahyuningsih, S. (2013). Mobile Internet Uses Among College Students. IPTEK-KOM. 15 2, 171-184 
Walsh, S.P., White, K. M., \& Young, R. M (2009). The Phone Connection: A Qualitative Exploration Of How Belongingness And Sosial Identification Elate To Mobile Phone Use Amongst Australian Youth. Journal of Community and Applied Social Psycology DOI: 10.1002/ casp.983

Widiantari, K.S \& Herdianto, Y.K. (2013). Perbedaan intensitas komukasi melalui jejaring sosial antara tipe kepribadian ekstrovert dan introvert pada remaja. Jurnal Psikologi
Udayana. Vol.1. No.1. 106-115. Uiversitas Udayana.

Wiyono, S.A. 2012, merdeka.com. ABG 14 tahun diperkosa pria yang dikenalnya lewat facebook. M.merdeka.com/peristiwa/abg-14tahun-diperkosa-pria-yang-di kenalnya-lewat-facebook.html diunduh tanggal 29 Maret 2015.

Yildirim, C. (2014). Exsploring the dimensions of nomophobia: developing and validating a questionnaire using mixed methods research. Graduate theses and dissertations. Diterbitkan. 